\title{
Analisis Citra Radiografi Panoramik pada Tulang Mandibula untuk Deteksi Dini Osteoporosis dengan Metode Gray Level Cooccurence Matrix (GLCM)
}

\author{
Azhari, ${ }^{1}$ Suprijanto, ${ }^{2}$ Yudhi Diputra, ${ }^{3}$ Endang Juliastuti, ${ }^{3}$ Agus Zainal Arifin ${ }^{4}$ \\ ${ }^{1}$ Radiologi Kedokteran Gigi, Universitas Padjadjaran Bandung, ${ }^{2}$ Laboratorium Instrumentasi Medik, \\ Kelompok Keahlian Instrumentasi dan Kontrol Fakulas Teknologi Industri, Institut Teknologi \\ Bandung, ${ }^{3}$ Fakultas Informatika Institut Teknologi Sepuluh November, Surabaya
}

\begin{abstract}
Abstrak
Osteoporosis salah satu penyakit degeneratif yang berkaitan dengan proses penuaan yang ditunjukkan perubahan struktur trabekula dan penurunan bone mineral density (BMD). Tujuan penelitian adalah mendapatkan metode kuantifikasi citra panoramik pada region of interest (ROI) di mandibula untuk menentukan BMD. Penelitian ini menggunakan ROI (80x80 pixel) pada kondilus mandibula untuk kuantifikasi citra dilakukan di Bagian Radiologi Fakultas Kedokteran Gigi Universitas Padjadjaran bulan Oktober sampai Desember 2013. Pendekatan analisis tekstur menggunakan prinsip gray level co-occurence matrix (GLCM). Desain dari kuantifikasi citra terdiri atas tahapan pelatihan dan pengujian. Tahapan pelatihan melalui 9 data latih terhadap subjek wanita berusia 52-73 tahun pascamenopause. Data BMD vertebra lumbar dari DEXA digunakan sebagai referensi pada tahap klasifikasi dengan support vector machine (SVM) dengan fungsi kernel multilayer perceptron. Pengujian digunakan 14 data uji dari subjek selain yang digunakan untuk data latih. Pengujian untuk klasifikasi kelas normal dan osteoporosis menggunakan SVM memberikan akurasi 85,71\%; sensitivitas (tingkat benar positif) 90,91\%; dan spesifisitas (tingkat benar negatif) 66,67\%. Pengenalan fitur paling baik didapatkan menggunakan kombinasi fitur contrast, correlation, energy, dan homogeneity sebagai input bagi klasifikasi SVM. Simpulan, analisis tekstur trabekula menggunakan metode gray level co-occurence matrix (GLCM) citra panoramik gigi dapat digunakan untuk deteksi dini osteoporosis. [MKB. 2014;46(4):203-8]
\end{abstract}

Kata kunci: Grey level co-occorance matrix (GLCM), panoramik, osteoporosis

\section{Panoramic Radiograph Image Analysis using Cooccurence Gray Level Matrix Method (GLCM) for Early Detection of Osteoporosis in Mandibular Bone}

\begin{abstract}
Osteoporosis is one of the degenerative diseases associated with aging, which is apparent from changes in trabecular structure and decreased bone mineral density (BMD) The aim of this study was to obtain a panoramic image quantification method on a region of interest (ROI) to determine the BMD. This study used an ROI (80x80 pixels) of the mandibular condyle for image quantification. The study was performed at the Department of Radiology, Faculty of Dentistry, Padjadjaran University during the period of October to December 2013. A texture analysis approach was applied using the principles of gray level co-occurence matrix (GLCM). The design of image quantification consisted of training and testing stages. The training stage was performed through 9 training data on the subjects of post-menopausal women between 52-73 years old. Data from the lumbar vertebrae BMD DEXA was used as a reference in the classification stage using a support vector machine (SVM) with kernel function multilayer perceptron. The testing used 14 test data from subjects which were not used for training data. The results showed that for the normal and osteoporotic class classification using SVM the accuracy was $85.71 \%$, sensitivity (true positive rate) was $90.91 \%$, and specificity (true negative rate) was $66.67 \%$. The best feature recognition was obtained using a combination of feature contrast, correlation, energy, and homogeneity as inputs for SVM classification. In conclusion, analysis of the trabecular texture using dental panoramic image produced by gray level co-occurance matrix (GLCM) method can be useful for early detection of osteoporosis. [MKB. 2014;46(4):203-8]
\end{abstract}

Key words: Grey level co-occorance matrix (GLCM), panoramic, osteoporosis

Korespondensi: Azhari, drg., M.Kes, Sp. RKG (K), Radiologi, Fakultas Kedokteran Gigi Universitas Padjadjaran Bandung, Jalan Sekeloa Selatan No.1 Bandung, mobile081322779900,e-mail azhariazhari79@yahoo.com 


\section{Pendahuluan}

Osteoporosis yaitu merupakan salah satu penyakit degeneratif yang sangat berkaitan dengan proses penuaan yang ditunjukkan penurunan kerapatan yang cepat dan juga penipisan jaringan tulang sehingga terjadi penurunan kekuatan mekanik tulang dalam upaya mendukung kondisi aktivitas normal. Berdasarkan atas deskripsi internasional, osteoporosis merupakan suatu penyakit tulang sistemik dengan karakteristik massa tulang yang rendah dan penurunan mikroarsitektur jaringan tulang, sehingga meningkatkan kerapuhan dan risiko patah tulang. ${ }^{1}$ Untuk saat ini DEXA adalah salah satu metode standar untuk mendeteksi terjadi osteoporosis. Hasil yang diberikan pada pemeriksaan DEXA adalah densitas tulang, merupakan banyaknya mineral tulang pada area dengan satuan gram per centimeter $\left(\mathrm{g} / \mathrm{cm}^{2}\right)$.

Masalah di Indonesia yaitu perangkat DEXA masih relatif terbatas pada rumah sakit di kota besar dan sering tidak mudah melakukan diagnosis khusus dengan menggunakan perangkat DEXA tersebut. ${ }^{2}$ Seiring dengan usia yang bertambah, tingkat kunjungan pasien ke dokter gigi semakin sering dilakukan berkaitan dengan konsultasi dan perawatan terhadap kondisi gigi dan mulut. Citra radiografi panoramik adalah jenis pencitraan secara ekstraoral sering dipergunakan dokter gigi sebelum melakukan tindakan. Citra radiografi panoramik gigi menjadi alternatif untuk diteliti setelah ditemukannya oleh Horner hubungan antara tulang mandibula dan bone mass density (BMD) vertebrae. ${ }^{1}$

Pada penderita osteoporosis postmenopause, jumlah trabekula akan mengalami penurunan oleh karena pengurangan hormon esterogen yang mengatur pembentukan matriks protein kolagen, nonkolagen, dan juga mineralisasi. ${ }^{3}$ Pengurangan estrogen sampai $75 \%$ dapat merangsang sitokin proinflamasi terbukti pada cairan sinovial dan internal kondilus. ${ }^{4}$ Proses ini lebih muda terjadi pada trabekula karena mempunyai metabolisme tinggi sehingga dapat terjadi sampai 5-8 kali dibandingkan dengan bagian kortikal. ${ }^{5}$ Perubahan yang terjadi pada permukaan trabekula sehingga terjadi penipisan trabekula, perforasi trabekula tipe plate, berkurang percabangan trabekula, dan perluasan area marrow jika berlanjut terus akan dapat terjadi osteoporosis. ${ }^{6}$ Kondisi tersebut menyebabkan perubahan kondisi absorsi $X$-ray pada tulang sehingga menghasilkan variasi dari kontras pada skala keabuan yang terekam pada citra.

Beberapa penelitian yang mempergunakan citra radiografi panoramik gigi untuk prediksi osteoporosis, antara lain dilakukan dengan cara mengukur lebar tulang korteks mandibula. ${ }^{7-9}$
Analisis densiti trabekula tulang mandibula. ${ }^{1,10-13}$

Pada penelitian ini diusulkan memilih region of interest (ROI) yang tidak mudah terpengaruh faktor lokal seperti infeksi kronik pada prosesus alveolar, infeksi pada akar gigi, dan beban oklusi pada bodi mandibula. Kondilus bagian dari mandibula merupakan bagian mandibula yang penting untuk dijadikan ROI, karena mempunyai beban besar dan mengandung banyak trabekula $(98,6 \%){ }^{14}$

Untuk prediksi osteoporosis, analisis citra pada ROI citra dilakukan dengan pendekatan analisis tekstur citra mempergunakan prinsip gray level co-occurence matrix (GLCM) dan juga ditentukan parameter statistik GLCM yang dikenal dengan fitur Harralic. Lalu dilakukan proses klasifikasi dengan menggunakan support vector machine (SVM) dengan fungsi kernel multilayer perceptron. Pada tahap awal SVM harus dilatih untuk melakukan pemetaan dari citra panaromik dengan kondisi BMD berdasarkan T-score. Selanjutnya dilakukan pengujian setelah proses pelatihan SVM memprediksi klasifikasi osteoporosis dari computer aided diagnosis yang divalidasi dengan kondisi BMD berdasarkan T-score untuk tiap subjek.

\section{Metode}

Penelitian ini menggunakan rancangan potong lintang terhadap data yang berupa citra radiografi panoramik gigi dan data hasil pengujian kerapatan mineral tulang dengan tes DEXA dari subjek yang sama. Data diperoleh dari Departemen Radiologi Kedokteran Gigi Universitas Padjadjaran.

Kriteria inklusi yaitu subjek berjenis kelamin wanita, berusia 52-73 tahun dan telah memasuki masa postmenopause. Subjek bersedia mengikuti penelitian dengan mengisi lembar persetujuan (informed consent). Izin penelitian didapatkan dari Komite Etik Penelitian Kesehatan Rumah Sakit Dr. Hasan Sadikin Bandung, Jumlah subjek sebanyak 23 orang. Pada semua subjek tersebut dilakukan pangambilan citra radiografi panoramik gigi mempergunakan orthopantomograph E-Woo EPX-Impla, pengaturan perangkat radiografi tegangan $66 \mathrm{kVp}$ dan arus tabung X-ray $8 \mathrm{~mA}$. Citra radiografi panoramik yang diperoleh dari orthopantomograph dipindahkan dan disimpan dalam format tagged image file format (TIFF) dengan ukuran 2840x1532 pixel dan resolusi $72 \mathrm{dpi}$, untuk selanjutnya dilakukan pengolahan data. Sebagai data pembanding baku standar untuk standardisasi subjek dilakukan uji DEXA pada bagian vertebra lumbar dan diperoleh hasil BMD tertinggi 2 dan terendah -4,5. Hasil ini menunjukkan bahwa subjek terdistribusi antara 


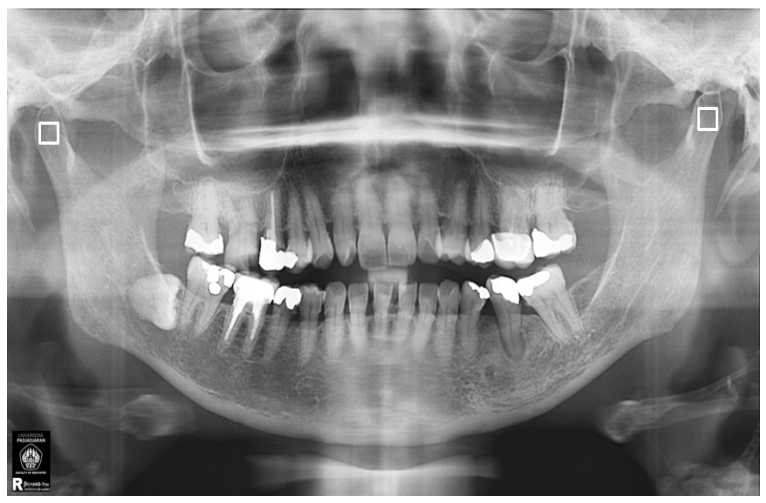

Gambar 1 Region of Interest Kondilus Mandibula

klasifikasi normal, osteopenia, dan osteoporosis.

Penentuan ROI untuk mendapatkan citra radiografi panoramik gigi terlihat pada Gambar 1, memuat berbagai informasi seperti citra susunan geligi, tulang mandibula, tulang maksila, rongga hidung, dan lain sebagainya. Pada penelitian ini ditentukan ROI bagian kondilus mandibula berukuran $80 \times 80$ pixel. Sistem analisis citra panoramik dengan rancangan umum sistem, persiapan data subjek, akuisisi citra radiografi panoramik gigi, penentuan ROI, peningkatan kualitas citra (image enhancement), dan analisis tekstur dari ROI yang diperoleh berdasarkan klasifikasi osteoporosis tersebut. Analisis tekstur mempergunakan pendekatan statistik metode GLCM. Fitur yang diperoleh dari GLCM dapat menunjukkan tingkat kerapatan mineral tulang dan dipergunakan sebagai input bagi SVM untuk klasifikasi citra radiografi panoramik gigi.

Sistem analisis DEXA yaitu metode penentuan kerapatan mineral tulang sebagai gold standard. Penggunaan DEXA menggunakan 2 energi foton $x$ ray yaitu 40 dan $70 \mathrm{kV}$ yang diperuntukkan untuk dapat membedakan jaringan lunak dengan

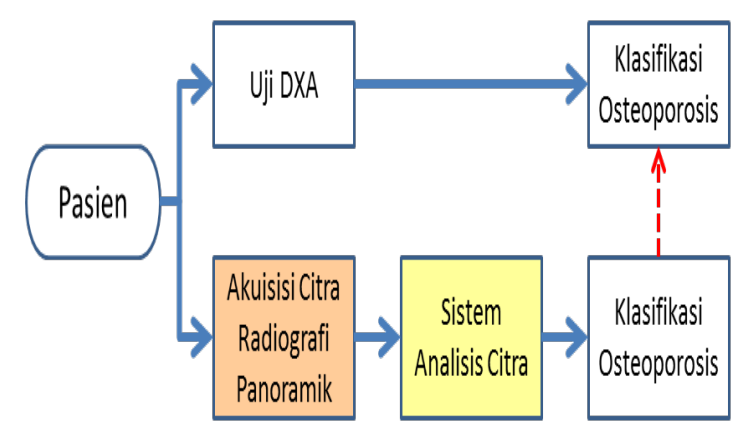

Gambar 2 Alur Penentuan Osteoporosis dari Citra Radiografi Panoramik Gigi tulang selanjutnya didapat perbedaan koefisien yang dihitung antara jaringan lunak dan keras. Data yang didapatkan berupa densitas gram $/ \mathrm{cm}^{2}$ disebut BMD. Penentuan klasifikasi osteoporosis menggunakan analisis citra radiografi panoramik gigi ini akan dibandingkan dengan hasil klasifikasi menggunakan metode DEXA.

Hasil klasifikasi hasil analisis citra kemudian dibandingkan dengan hasil pengujian DEXA sebagai suatu umpan balik untuk meningkatkan keakurasian sistem yang diusulkan tersebut. Pada penelitian ini diusulkan metode analisis tekstur dengan pendekatan statistik untuk menentukan tingkat osteoporosis dengan menilai region of interest yang telah ditentukan dari citra radiografi panoramik gigi subjek. Citra hasil cropping dari ROI ini kemudian akan ditingkatkan kualitas citranya menggunakan ekualisasi histogram sehingga antara objek dan latar dapat dipisahkan. Selanjutnya, citra tersebutyang sudah ditingkatkan kualitasnya akan melalui proses analisis tekstur dengan metode GLCM untuk mendapat ekstraksi fitur yang akan digunakan sebagai input bagi SVM untuk klasifikasi osteoporosis. Fitur kontras adalah mengukur banyaknya variasi lokal pada suatu citra, sedangkan fitur energi, mengukur keseragaman tekstur pada pengulangan pixel yang berpasangan. Fitur korelasi dapat mengukur ketergantungan linier tingkat keabuan pada citra. Fitur homogenitas mengukur homogenitas citra dan mempunyai nilai maksimum ketika semua elemen pada citra sama.

Ekstraksi fitur GLCM dari citra menunjukkan indikasi untuk memisahkan antara kelas normal dan osteoporis, paling baik dengan ekstraksi fitur untuk jarak $\delta=1$ dan orientasi sudut yang diamati adalah sudut $0^{\circ}, 45^{\circ}, 90^{\circ}$, dan $135^{\circ}$. Dari hasil range nilai fitur kelas osteopenia dimasukkan ke dalam kelas normal pada proses klasifikasi oleh karena nilai kelas osteopenia yang tumpang tindih dengan kelas normal dan juga osteoporosis (Gambar 3).

Sistem analisis citra panoramik, pengujian terhadap metode, dan sistem yang telah dirancang

\section{Tabel 1 Baku Emas}

\begin{tabular}{|c|c|c|c|c|}
\hline \multirow{4}{*}{$\begin{array}{l}\text { Hasil } \\
\text { Uji }\end{array}$} & & $\mathrm{Ta}$ & Tidak & Jumlah \\
\hline & Ya & A & B & $A+B$ \\
\hline & Tidak & C & D & $\mathrm{C}+\mathrm{D}$ \\
\hline & & $\mathrm{A}+\mathrm{C}$ & $B+D$ & $\mathrm{~A}+\mathrm{B}+\mathrm{C}+\mathrm{D}$ \\
\hline
\end{tabular}

Keterangan: Sensitivitas $=A /(A+C) \times 100$ Spesifisitas $=D /(B+D) \times 100$ dan Akurasi $=A+D / A+B+C+D \times 100$ 


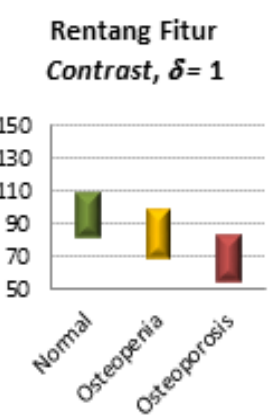

$\mathbf{a}$
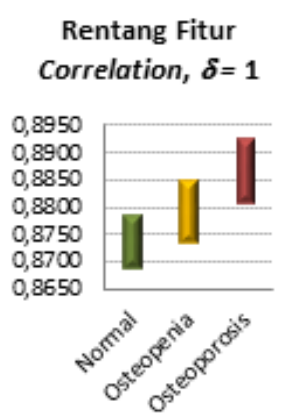

b

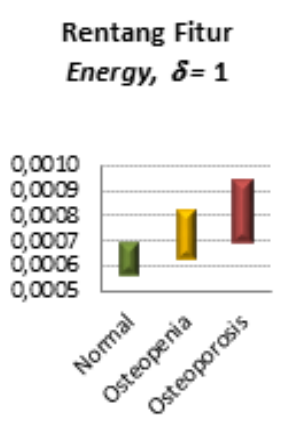

c

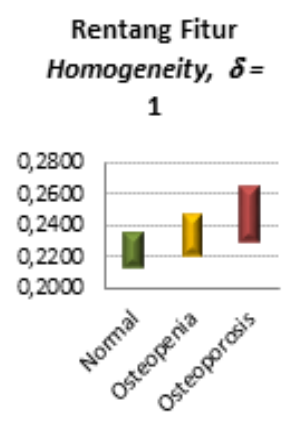

d

Gambar 3 Grafik Rentang Ekstraksi Fitur GLCM dengan $\delta=1$, a) Contrast, b) Correlation, c) Energy, d) Homogeneity

dilakukan dengan memakai parameter akurasi, sensitivitas, dan spesifisitas.

\section{Hasil}

Hasil klasifikasi menggunakan metode DEXA. Dari hasil rata-rata nilai fitur kelas osteopenia dimasukkan ke dalam kelas yang normal pada proses klasifikasi karena nilai kelas osteopenia tumpang tindih dengan kelas normal (Gambar 4). Penggunaan beberapa fitur GLCM sebagai input pada proses klasifikasi atau hasil pengujian menunjukkan terjadi peningkatan nilai akurasi, sensitivitas, dan spesifisitas.

Ekstraksi fitur tersebut dijadikan sebagai input tunggal dan kombinasi 2, 3, dan 4 fitur. Dari hasil pengujian terlihat bahwa fitur energi mempunyai pengenalan paling baik terhadap kelas normal dengan sensitivitas 100\%. Fitur paling baik untuk pengenalan kelas osteoporosis adalah correlation dengan spesifisitas $66,67 \%$. Penggunaan beberapa fitur GLCM sebagai input pada proses klasifikasi hasil pengujian menunjukkan peningkatan nilai akurasi, sensitivitas, dan spesifisitas. Pada model kombinasi fitur yang menggunakan 3 fitur dan 4 fitur sebagai input klasifikasi, akurasi semakin baik dengan nilai 78,57 sampai $85,71 \%$. Naiknya kemampuan pengenalan sistem dipengaruhi fitur energi dan correlation yang digunakan pada kombinasi fitur sebagai input klasifikasi.

\section{Pembahasan}

Secara keseluruhan, perfomansi pengenalan yang paling baik diperoleh pada penggunaan kombinasi 3 fitur (contrast, correlation, homogeneity) dan juga kombinasi 4 fitur (contrast, correlation, energi, homogeneity) dengan akurasi 85,71\%; sensitivitas 90,91\%; dan spesifisitas $66,67 \%$. Dari hasil kemampuan pengenalan individu fitur dan kemampuan pengenalan kombinasi fitur,

Tabel 2 Data Kerapatan Mineral Tulang dan Klasifikasi Subjek Penelitian

\begin{tabular}{ccl}
\hline No. Sampel & Nilai BMD & $\begin{array}{c}\text { Klasifikasi } \\
\text { Osteoporosis }\end{array}$ \\
\hline 1 & 0,3 & Normal \\
2 & $-0,7$ & Normal \\
3 & -3 & Osteoporosis \\
4 & $-4,5$ & Osteoporosis \\
5 & $-1,3$ & Osteopenia \\
6 & $-2,4$ & Osteopenia \\
7 & $-3,5$ & Osteoporosis \\
8 & $-1,4$ & Osteopenia \\
9 & 2 & Normal \\
10 & $-2,6$ & Osteoporosis \\
11 & $-0,2$ & Normal \\
12 & $-2,8$ & Osteoporosis \\
13 & $-2,8$ & Osteoporosis \\
14 & $-1,4$ & Osteopenia \\
15 & $-2,5$ & Osteoporosis \\
16 & $-1,2$ & Osteopenia \\
17 & $-1,2$ & Osteopenia \\
18 & $-0,9$ & Normal \\
19 & $-1,9$ & Osteopenia \\
20 & -2 & Osteopenia \\
21 & -2 & Osteopenia \\
22 & -2 & Osteopenia \\
23 & -2 & Osteopenia \\
\hline
\end{tabular}


Perbandingan Hasil Pengenalan Berdasarkan Kombinasi Fitur

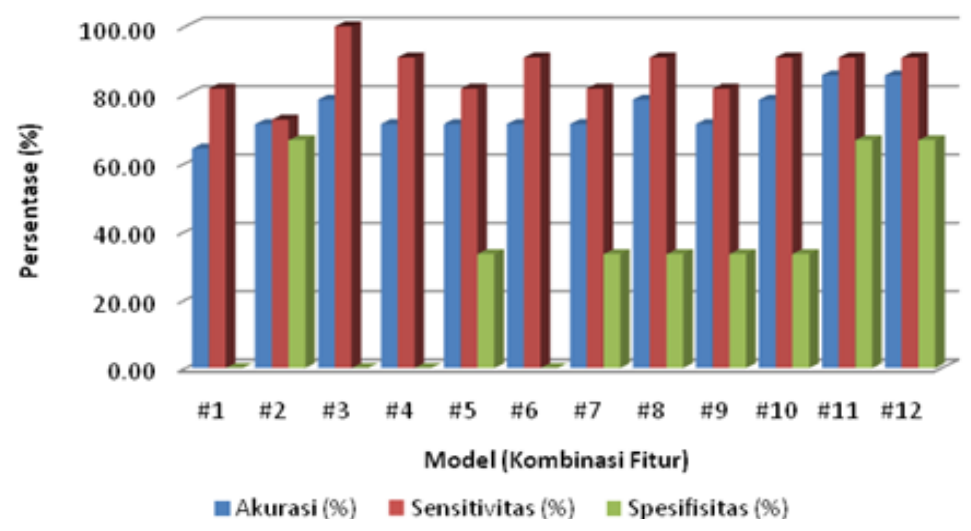

Gambar 4 Grafik Perbandingan Performansi Pengenalan Tingkat Kerapatan Mineral Tulang berdasarkan Kombinasi Fitur GLCM pada Kondilus Kiri dan Kanan

maka input yang paling baik untuk digunakan dalam klasifikasi kerapatan mineral tulang adalah kombinasi fitur contrast, correlation, energi, dan homogen.

Pengenalan kondisi kerapatan mineral tulang yang belum mampu mencapai hasil 100\% pada penelitian ini dapat disebabkan oleh kemampuan radiografi dalam mendeteksi perubahan kualitas tulang. Perbedaan kualitas citra panoramik yang disebabkan karena perbedaan posisi dan ukuran kepala pasien yang akan memengaruhi proyeksi radiograf panoramik. Perbedaan proyeksi akan memengaruhi atenuasi dan distorsi tulang citra panoramik. Di samping hal itu, faktor fisiologi kondilus yang cenderung menerima beban tidak sama besar dan perbedaan keseimbangan kiri dengan kanan dalam sistem stomatognati.

Tulang kondilus merupakan tulang paling aktif pada pergerakan di sistem stomatognati., Kondilus adalah bagian dari temporo mandibular joint (TMJ) yang banyak menerima tekanan pada saat pengunyahan, beban pengunyahan ini bervariasi besarnya bergantung pada kebiasaan, jenis makanan, dan juga pola pengunyahan. ${ }^{18}$ Kondilus terdiri atas kepala kondilus dan leher. Kondilus terdiri atas sebagian besar yaitu tulang trabekula $(98,6 \%)$ dan hanya sebagian kecil kompakta $(1,4 \%) .{ }^{14}$ Proporsi trabekula pada kondilus dan tidak terlalu banyak faktor lokal yang mengganggu merupakan dasar pemilihan ROI kondilus.

Penelitian berdasarkan trabekula ini juga terbukti pada binatang percobaan karena analisis berdasarkan pola trabekula dapat memdeteksi perubahan kualitas tulang tersebut sebesar 94\%, sedangkan berdasarkan kortikal hanya $64 \%$. $^{7}$

Perubahan yang terdapat dalam rongga mulut yang mengarah ke perubahan trabekula seperti resorpsi tulang alveolar, mobiliti gigi. Penelitian pada tikus percobaan yang dilakukan ovariektomi (model osteoporosis) terjadi perubahan pola trabekula pada mandibula setelah dua minggu ovariektomi dan terjadi penurunan ketebalan kortikal setelah 16 minggu. ${ }^{17}$ Penurunan pada pola trabekula terbesar pada tibia $36 \%$, sedangkan mandibula $16 \%{ }^{9}$ menunjukkan bahwa trabekula mempunyai reaksi yang lebih cepat terhadap perubahan kadar estrogen. ${ }^{6}$ Kendala terbesar karena banyak faktor lokal yang memengaruhi seperti faktor oklusi dan iritasi infeksi kronik, dan trauma fisik yang sulit dihindari. ${ }^{5,8}$

Analisis citra radiografi panoramik dengan ROI pada kondilus dapat digunakan sebagai dasar computer-aided diagnosis dalam memberikan informasi dini tentang terjadinya osteoporosis. Ekstraksi fitur contrast, correlation, energi, dan homogeneity pada trabekula tulang kondilus mandibula citra radiografi panoramik gigi mampu mengidentifikasi nilai kerapatan mineral tulang normal dan osteoporosis. Kombinasi fitur GLCM yang memberikan tingkat pengenalan kerapatan mineral tulang paling maksimal pada klasifikasi SVM fungsi kernel multilayer perceptron adalah kombinasi semua fitur contrast, correlation, energi, dan homogeneity dengan nilai akurasi $85,71 \%$; sensitivitas $90,91 \%$; dan spesifisitas $66,67 \%$ (Gambar 4).

Simpulan, analisis tekstur trabekula memakai metode grey level co-occurrence matrix (GLCM) pada radiograf panoramik dapat digunakan untuk deteksi dini osteoporosis.

\section{Daftar Pustaka}

1. Arifin AZ, Yuniarti A, Dewi LR, Asano A, 
Taguchi A, Nakamoto T. Computer-aided diagnosis for osteoporosis base on trabecular bone analysis using panoramic radiographs. Dental J. 2010;43:107-12.

2. Susilo, Budi WS, Kusminarto, Yunita I. Kajian spine phantom dengan teknik radiografi dexa. Proceeding Seminar Nasional Keselamatan PLTN Nuklir, Surakarta: 2009.

3. Ejiri S, Tanaka M, Watanabe N, Binte R Yamashita E. Estrogen deficiency and effecton the jaw bones. J Bone Miner Metab. 2008:26:409-15.

4. Qing-Yu W, Juan D, Bing K, Jie Z, ShiBin Y, Yin-Zhong D dkk. Osteochondral angiogenesis in rat mandibular condyle with osteoarthritis. J Oral Biol. 2012;10:620-9.

5. White SC. Oral radiographic predictors of osteoporosis. J Dentomaxillofacial Radiol. 2002;31:84-92.

6. Jie Yang, Pham SM, Crabbe DL. Effects of estrogen deficiency on rat mandibular and tibial microarchitecture. J Med Oral Patol Oral Cir Bucal. 2012;17(4):624-32.

7. Shimamoto M, Kozai Y, Matsumoto Y, Kawamata R, Sakurai T, Kashima I. Radiological morphometry analisis for the trabecular bone structur of mandibular condyle after ovariectomy in mature cynomolgus monkeys. Oral Sci International. 2007;4(2):86-96.

8. Taguchi A, Ohtsuka M, Tsuda M, Nakamoto $\mathrm{T}$, Kodama, Inagaki $\mathrm{K}$, dkk. Risk of vertebral osteoporosis in post menopausal women with alterations of the mandible, $\mathrm{J}$ Dentomaxillofacial Radiol. 2007;36:143-8.

9. Hardanti S, Azhari, Oscandar F. Description of mandibular bone quality based on measurement of cortical thickness using Mental index of male and female patients between 40-60 years old. J Imaging Sci Dentistry. 2011;41:151-7.

10. Watanabe PCA, Morphodigital study of the mandibular trabecular bone in panoramic radiographs. Int J Morphol. 2007;4:25-60.
11. Stauber M, Muller R. Age related changes in trabecular bone microstructure: global and lokal morphometry. Int $\mathrm{J}$ Osteoporosis. 2005;6:10-25.

12. Muhlberger G, Svejda D, Lotterberger C, Rudiger E, Putz Reinhard P. Mineralization density apparent density in mandibular condyle bone. J Oral Surg Oral Med Oral Path Oral Radiol End. 2009;107(4):573-9.

13. Amer $\mathrm{MH}, \mathrm{HeO} \mathrm{MH}$, Brook SL, Benavides E. Anatomical variation of trabecular bone structure in intra oral radiographs using fractal and particle count analysis. J Imaging Sci Dentistry. 2012;42:5-12.

14. Cakur B, Dagistan S, Sahin A, Harorli A, Yilmaz AB. Reliability of mandibular cortical index and mandibular bone mineral density in the detection of osteoporotic women. J Dental Maxillofacial Radiol. 2009;38(5):255-6.

15. Taguchi A, Ohtsuka M, Nakamoto T, Suei Y, Kudo Y, Tanimoto K, dkk. Detection of postmenopausal woman with low bone mineral density and elevated biochemical marker of bone turnover by panoramic radiograps. Dento Maxillo Radiol. 2008;37:433-7.

16. Van Eijden TMGJ, Van Hel, Van Ruijven LJ, Mulder L. Structur and mechanical properties of mandibular condylar bone. J Dent Res. 2006;85:33-7.

17. Hegde S, Praveen BN, Shetty SR. Morphological and radiological variations of mandibular condyles in health and diseases: a systematic review. J Dentistry. 2013;3:1-5.

18. Coel L, Last D, Duboeuf F, Seurin MJ, Lissac M, Briguet A, dkk. Trabecular alveolar bone microarchitecture in the human mandible using high resolution magnetic resonance imaging. Dento Maxillofac Radiol. 2004;33(3): 177-82.

19. Huh KH, Baik SJ, Won JY, Heo MS, Lee SS, Choi SC, dkk. Fractal analisis of mandibular trabecular bone. optimal tile sizes for the tile counting method. Imaging Sci Dentistry. 2011;41(2):71-8. 